\title{
TEKANAN EKONOMI, INTERAKSI ORANG TUA-REMAJA, DAN PERKEMBANGAN SOSIAL EMOSI REMAJA
}

\author{
Rina Fatimah ${ }^{1 *}$, Euis Sunarti², Dwi Hastuti ${ }^{2}$ \\ ${ }^{1}$ Dompet Dhuafa, Program Studi llmu Keluarga dan Perkembangan Anak, Sekolah Pascasarjana, \\ IPB University, Bogor 16680, Indonesia \\ ${ }^{2}$ Departemen IImu Keluarga dan Konsumen, Fakultas Ekologi Manusia, \\ IPB University, Bogor 16680, Indonesia
}

")E-mail: rin_fattye@yahoo.com

\begin{abstract}
Abstrak
Capaian perkembangan sosial emosi sangat penting bagi remaja dalam kehidupan bermasyarakat. Capaian perkembangan sosial emosi dapat dipengaruhi oleh kualitas interaksi orang tua-remaja dan tekanan ekonomi keluarga. Penelitian ini bertujuan untuk menganalisis pengaruh tekanan ekonomi dan interaksi orang tua-remaja terhadap perkembangan sosial emosi remaja pada keluarga yang tinggal di Rusunawa Jatinegara Barat. Contoh penelitian yakni keluarga yang memiliki anak remaja dengan rentang usia 13 sampai 18 tahun dengan teknik penarikan contoh secara disproportional random sampling berjumlah 120 keluarga terdiri dari 60 keluarga dengan anak remaja laki-laki dan 60 keluarga remaja perempuan. Hasil penelitian menunjukkan bahwa pada tekanan ekonomi objektif, lebih dari separuh ayah remaja laki-laki dan remaja perempuan memilki status pekerjaan tidak tetap. Rataan indeks tekanan ekonomi subjektif keluarga remaja laki-laki sebesar 31,92 dan keluarga remaja perempuan sebesar 33,70. Dimensi penerimaan ibu dan ayah memiliki rataan skor tertinggi pada interaksi orang tua-remaja. Dimensi ekspresi emosi dan ekspresi sosial memiliki rataan skor tertinggi pada perkembangan sosial emosi remaja. Pendapatan perkapita keluarga dan dimensi penerimaan ayah interaksi ayah-remaja berbeda antara keluarga remaja laki-laki dan perempuan. Hasil uji model pengaruh membuktikan bahwa usia remaja dan interaksi ibu-remaja berpengaruh langsung positif pada perkembangan sosial emosi remaja; sementara tekanan ekonomi objektif berpengaruh tidak langsung negatif terhadap perkembangan sosial emosi remaja melalui interaksi ibu-remaja.
\end{abstract}

Kata kunci: interaksi keluarga, interaksi orang tua-remaja, perkembangan sosial emosi, remaja, tekanan ekonomi

\section{Economic Pressure, Parent-Adolescent Interaction, and Adolescent's Social-Emotional Development}

\begin{abstract}
The achievement of social-emotional development is very important for adolescents in social life. The achievement of social-emotional development can be influenced by the quality of parent-adolescent interactions and economic pressures. This study aimed to analyze the influence of economic pressures and parent-adolescent interactions on the social-emotional development of adolescents in the family who live in "Rusunawa" of West Jatinegara. Samples of this study are families who have adolescents aged 13-18 years consisting of 60 boy families and 60 girl families that were chosen by disproportional random sampling. The respondents of this study are adolescents with their mothers. The results of objective economic pressure shows that more than half of the fathers of adolescents have precarious employment status. The average subjective economic pressure index for the families of boys is 31,92 and for families of girls is 33,70. The dimension of acceptance of mother and father has the highest average score on parent-adolescents interactions. Dimensions of emotional expressivity and social expressivity have the highest average score on the social development of adolescent emotions. There were differences between boys' and girls' family on per capita family income and the father's acceptance dimension of father-adolescent interaction. The test results of the influence model prove that adolescents' age and motheradolescent interactions have a direct positive influence on the social development of adolescent emotions; while objective economic pressures have an indirect negative effect on the social development of adolescent emotions through mother-adolescent interactions.
\end{abstract}

Keyword: adolescent, development of social-emotional, economic pressure, family interaction, parent-adolescent interaction 


\section{PENDAHULUAN}

Menjelang tahun 2020, usia produktif di Indonesia akan mencapai 70 persen. Kondisi ini disebut dengan bonus demografi (BKKBN, 2017). Adanya peningkatan frekuensi kenakalan remaja tentu saja akan membawa kerugian bagi bangsa Indonesia karena remaja saat inilah yang akan mengisi bonus demografi tahun 2025. Berdasarkan data Komisi Perlindungan Anak Indonesia (KPAl), rentang waktu tahun 2011-2017 diketahui bahwa 9.674 anak berhadapan dengan hukum, 2.393 anak berhadapan dengan kasus kesehatan, dan NAPZA (Riska \& Krisnatuti, 2018). Menurut Unayah dan Sabarisman (2016), kenakalan remaja saat ini, seperti yang diberitakan oleh berbagai media, sudah dikatakan melebihi batas sewajarnya. Aksi tawuran yang dilakukan oleh geng motor tidak hanya menggunakan senjata tajam tapi juga senjata tumpul yang digunakan agar lawan mengalami cidera dan meminta ampun (Armayati, Iskandar, Siswandi, \& Abidin, 2019). Menurut Setiawan (2016), kekerasan yang dilakukan oleh remaja seperti tawuran dianggap sebagai pemecah masalah yang sangat efektif.

Perilaku remaja yang mengarah pada tindakan kriminalitas menandakan adanya ketidakmampuan remaja menjalin hubungan baik dengan lingkungan dan menjalankan norma masyarakat. Hal ini disebabkan adanya dinamika perubahan psikologis yang tidak terkontrol pada diri remaja dan faktor eksternal seperti kurangnya perhatian dari orang tua dan keadaan lingkungan keluarga menyebabkan remaja rentan untuk terlibat dalam kasus-kasus kriminalitas (Sumara, Humaedi, \& Santoso, 2017). Oleh sebab itu, remaja dituntut untuk memiliki kemampuan penyesuaian sosial baik di dalam lingkungan keluarga, sekolah, dan masyarakat (Rahayu \& Hartati, 2015). Berdasarkan penelitian Wardani dan Apollo (2010), remaja perempuan mempunyai penyesuaian sosial lebih tinggi daripada remaja laki-laki. Penyesuaian sosial merupakan awal perkembangan sosial emosi remaja dan merupakan salah satu hal terpenting dalam fase remaja karena menjadi landasan kuat untuk meraih keberhasilan pada tugas perkembangan selanjutnya (Andayani, 2010). Perkembangan sosial emosi yakni istilah umum yang menggambarkan berbagai keterampilan interpersonal dan intrapersonal individu termasuk memahami, mengatur, dan mengekpresikan emosi dengan cara yang sesuai untuk usia dan perkembangan seseorang serta kemampuan untuk membangun, mempertahankan, dan mengembangan hubungan yang sehat dengan teman sebaya dan orang dewasa (Malti \& Noam, 2016). Keterampilan sosial merupakan salah satu aspek dari perkembangan sosial emosi yang akan membantu remaja dalam memahami lingkungan, memahami cara berinteraksi, dan berkomunikasi serta memunculkan perilaku yang dapat diterima dan diharapkan oleh lingkungannya (Hastuti, 2008; Larasati \& Marheni, 2019).

Orang tua adalah aktor utama yang memengaruhi anak dan sumber daya bagi kehidupan anak. Menurut Berns (1993), perkembangan dan pembentukan remaja dalam kehidupan sehari-hari terkait erat dengan interaksi di dalam keluarga. Interaksi yang berlangsung antara orang tua dengan remaja dalam bentuk pemberian kasih sayang, pemberian pemenuhan kebutuhan anak, pengarahan dan perlindungan termanifestasi dalam bentuk pengasuhan (Sunarti, 2012). Penelitian Riska dan Krisnatuti (2018) menunjukkan bahwa remaja yang memperoleh pengasuhan penerimaan yang semakin tinggi dari ibunya cenderung memiliki self-esteem yang lebih tinggi. Pengasuhan penolakan (kekerasan dan penolakan) membuat selfesteem remaja semakin rendah. Penelitian lain yang dilakukan oleh Asilah dan Hastuti (2019) mengatakan bahwa adanya hubungan penerimaan ibu yang tinggi dapat meningkatkan harga diri remaja. Pengasuhan dengan kekerasan dan pengabaian akan mengurangi harga diri remaja dan meningkatkan perilaku perundungan pada remaja. Menurut Steinberg (2001), terdapat bukti yang menyimpulkan bahwa remaja mendapat manfaat dari pengasuhan orang tua yang hangat, kuat, dan menerima kebutuhan akan otonomi psikologis remaja. Pola asuh orang tua, baik yang menerima (acceptance) maupun yang menolak (rejection) anaknya akan memengaruhi perkembangan emosi, perilaku, sosial kognitif, serta fungsi psikologinya (Khaleque \& Rohner, 2002).

Interaksi orang tua-remaja melalui pengasuhan dapat dipengaruhi oleh permasalahan yang dihadapi oleh keluarga salah satunya yakni kesulitan ekonomi. Keluarga yang berhadapan pada situasi kesulitan ekonomi karena adanya penurunan tingkat pendapatan, ketidakstabilan pekerjaan, dan ketidakmampuan dalam membayar hutang akan menciptakan tekanan ekonomi (Conger et al., 1992). Tekanan ekonomi merupakan sindrom peristiwa atau kondisi yang memberikan pengalaman psikologis seperti stres akan kesulitan ekonomi (Gudmunson, 2010). Keluarga yang mengalami 
tekanan ekonomi akan melakukan adaptasi. Penelitian Sunarti, Atat, Noorhaisma, dan Lembayung (2005) menyebutkan tekanan ekonomi adalah suatu kondisi yang diukur dengan melihat tekanan ekonomi secara aktual dan tekanan ekonomi keluarga secara persepsi yang dirasakan keluarga. Tekanan ekonomi aktual adalah suatu kondisi yang diukur dengan melihat keadaan ekonomi keluarga secara nyata, seperti kepemilikan aset, hutang, pendapatan keluarga dan status pekerjaan. Menurut Conger, Conger, Matthews, dan Elder (1999), remaja sebagai bagian dari anggota keluarga dapat memberikan penilaian tentang kesulitan ekonomi yang dihadapi keluarga. Penilaian remaja terhadap kesulitan ekonomi yang dihadapi keluarga memberikan pengaruh pada emotional distress dan ketercapaian perkembangan remaja.

Remaja dengan orang tua dalam tekanan ekonomi beresiko untuk memperoleh pengasuhan kekerasan dan tentu saja akan memengaruhi capaian perkembangan remaja (Simons, Whitbeck, \& Wu, 1994) dan remaja akan mencontoh gaya interaksi yang dipelajari dari orang tuanya dalam hubungan pertemanan seperti meniru orang tua dalam menangani konflik dengan paksaan dibandingkan dengan bernegoisasi (Downey \& Coyne, 1990). Menurut Galambos dan Silbereisen (1987), tekanan ekonomi memengaruhi perubahan perilaku pengasuhan pada ayah yang lebih bersifat menghukum, sewenang-wenang, dan menolak berdampak pada perasaan ketidakmampuan diri dan pencapaian rendah pada remaja perempuan usia 13 sampai 16 tahun. Pada penelitian di Bogor, makin tinggi tingkat tekanan ekonominya maka akan makin rendah kualitas pernikahan, kualitas pengasuhan, kecerdasan emosi anak, dan pencapaian akademik anak (Sunarti et al., 2005).

Pada akhir tahun 2015, terjadi relokasi warga bantaran sungai Ciliwung, kawasan Kampung Pulo ke Rumah Susun Sewa (Rusunawa) Jatinegara Barat sebagai dampak dari program normalisasi Sungai Ciliwung untuk mengurangi masalah banjir di DKI Jakarta. Penelitian deskriptif yang dilakukan oleh Syafruddin dan Adi (2017) menunjukkan bahwa sebelum pindah ke lokasi rusunawa, pengeluaran keluarga hanya sekitar Rp50.000,00 Rp100.000,00 per bulan yang dikeluarkan untuk membayar listrik saja dan sebagian keluarga mempunyai usaha rumah kontrakan atau kamar kos. Setelah direlokasi, besar pengeluaran keluarga meningkat menjadi sekitar Rp600.000,00-Rp700.000,00 per bulan.
Hal ini menyebabkan pengeluaran keluarga menjadi beban karena rendahnya pemasukan keluarga sehingga tunggakan sewa yang makin besar yang tidak dapat dibayar oleh keluarga.

Menurut Conger et al. (1992), kesulitan ekonomi ditandai dengan ketidakmampuan keluarga membayar tagihan bulanan seperti sewa rumah atau tidak terpenuhinya kebutuhan bulanan. Penelitian Leinonen, Solantaus dan Punamäki (2002) menunjukkan kesulitan ekonomi menciptakan tekanan ekonomi bagi orang tua. Adanya tekanan ekonomi akan memberikan dampak pada kesehatan mental sehingga memengaruhi dukungan perkawinan yang rendah. Interaksi perkawinan negatif dikaitkan dengan pengasuhan yang buruk, terutama para ayah. Tekanan ekonomi berpengaruh langsung terhadap interaksi ayah dan ibu yang tidak hangat dengan cenderung adanya kekerasan dalam pernikahan (Conger et al., 1999) yang berimplikasi pada pengasuhan negatif (Leinonen et al., 2002). Menurut hasil penelitian Elder, Van-Nguyen dan Caspi (1985), kesulitan ekonomi yang dialami keluarga meningkatkan perilaku penolakan pada ayah, secara negatif memengaruhi kesejahteraan psikososial anak perempuan, tetapi tidak pada anak laki-laki.

Kualitas interaksi orang tua-anak akibat tekanan ekonomi, cenderung kurang sensitif dan responsif terhadap kebutuhan anak, kurang hangat, lebih kritis, dan lebih banyak menolak (Weiss, 2009) berpengaruh terhadap perkembangan sosial emosi sebagai dampak dari perilaku orang tua dalam menghadapi anak (Mc Loyd, 1990). Penelitian yang dilakukan oleh Stein et al. (2013) menunjukkan bahwa persepsi remaja tentang kesulitan ekonomi yang dihadapi keluarga dapat memrediksi penyesuaian yang dilakukan oleh remaja sehingga memberikan pengaruh pada hubungan orang tua-remaja dan berdampak pada pencapaian perkembangan remaja.

Penelitian di rusunawa pernah dilakukan oleh Permatasari dan Sastrawan (2018) terkait kapasitas hunian yang menemukan hasil bahwa jumlah hunian yang tinggal pada unit hunian rumah susun umumnya melebihi kapasitas ideal yang seharusnya ditampung. Fenomena lebihnya penghuni dalam unit hunian berhubungan dengan kepadatan dan kesesakan dalam ruang tertentu. Menurut Sari dan Karyono (2017), kesesakan berkorelasi positif terhadap perilaku agresivitas remaja. Hal ini mengandung arti bahwa faktor lingkungan sosial yang menjadi tempat tinggal remaja saat ini berpotensi timbulnya perilaku agresi. 
Berdasarkan hasil penelitian Purwaningsih, Tukiran dan Giyarsih (2011) menunjukkan bahwa interaksi antarpenghuni relatif berkurang karena lelah untuk naik turun antara satu lantai dengan lantai yang lain dan minimnya waktu untuk beinteraksi secara intens. Dapat disimpulkan, remaja di rusunawa berpotensi pada rendahnya capaian perkembangan sosial emosi remaja.

Penelitian tentang tekanan ekonomi, interaksi orang tua-remaja, dan perkembangan sosial emosi remaja belum banyak dilakukan; khususnya pada remaja dan keluarganya yang tinggal di rusunawa yang mempunyai karakteristik yang khas. Oleh karena itu, perlu dilakukan penelitian untuk mengetahui faktorfaktor apa saja yang memengaruhi perkembangan sosial emosi remaja pada keluarga khususnya yang tinggal di rusunawa. Tujuan penelitian ini adalah mengidentifikasikan karakteristik remaja, karakteristik keluarga, tekanan ekonomi, interaksi orang tua-remaja, dan perkembangan sosial emosi remaja; menganalisis uji beda tekanan ekonomi, interaksi orang tua-remaja, dan perkembangan sosial emosi remaja menurut jenis kelamin; dan menganalisis pengaruh karakteristik remaja, karakteristik keluarga, tekanan ekonomi, dan interaksi orang tua-remaja terhadap perkembangan sosial emosi remaja.

\section{METODE}

Penelitian ini menggunakan desain penelitian cross sectional study. Lokasi penelitian dipilih secara purposive yaitu rusunawa di bawah pengelolaan Pemerintah Provinsi DKI Jakarta. Populasi penelitian ini adalah keluarga yang memiliki remaja di rusunawa Jatinegara Barat. Contoh dalam penelitian ini adalah keluarga yang memiliki remaja dengan rentang usia 13 sampai 18 tahun. Berdasarkan data yang diperoleh terdapat 196 keluarga dengan anak remaja di rusunawa Jatinegara yang terdiri dari 104 keluarga yang memiliki anak remaja lakilaki dan 92 keluarga dengan remaja perempuan. Teknik penarikan contoh menggunakan teknik disproporsional random sampling dengan jumlah contoh yang diambil untuk penelitian ini sebanyak 60 remaja laki-laki dan 60 remaja perempuan. Namun, data yang dapat diolah sebanyak 119 yang terdiri dari 60 keluarga dengan remaja laki-laki dan 59 keluarga dengan remaja perempuan. Hal ini dikarenakan terdapat dua remaja perempuan yang memiliki hubungan darah (kakak-adik) sehingga dipilih salah satu. Responden penellitian yakni remaja beserta ibu. Data dikumpulkan melalui teknik wawancara dengan alat bantu kuesioner yang dijawab oleh ibu dan remaja. Kuesioner yang ditanyakan kepada ibu adalah tekanan ekonomi objektif. Kuesioner yang ditanyakan kepada remaja adalah tekanan ekonomi subjektif, interaksi orang tuaremaja, dan perkembangan sosial emosi remaja.

Penelitian Sunarti (2005) menyebutkan bahwa tekanan ekonomi adalah suatu kondisi yang diukur dengan melihat tekanan ekonomi secara aktual dan tekanan ekonomi keluarga yang dipersepsikan dari apa yang dirasakan keluarga. Firdaus dan Sunarti (2009) mengukur tekanan ekonomi objektif keluarga dengan pendapatan per kapita, perbandingan pendapatan dan pengeluaran, rasio hutang dengan aset, dan status pekerjaan. Sementara itu, tekanan ekonomi subjektif remaja diukur dengan menggunakan instrumen penelitian Conger et al. (1999) yang terdiri dari adolescent perceptions of family hardship dan adolescent hardship experiences. Pertanyaan dijawab dengan empat poin skala Likert (yang kemudian diberi skor $0=$ tidak pernah hingga 3 = selalu) dengan Cronbach's alpha 0,697.

Interaksi yang berlangsung antara orang tua dengan anak berbentuk pemberian kasih sayang, pemberian pemenuhan kebutuhan anak, pengarahan dan perlindungan adalah suatu bentuk pengasuhan (Sunarti, 2012). Interaksi orang tua-remaja diukur dengan menggunakan variabel pengasuhan Parental Acceptance-Rejection Questionnaire/Control Questionnaire (PARQ/Control) merupakan adopsi penelitian yang dilakukan oleh Kim (2008). PARQ digunakan untuk menilai persepsi remaja terkait pengasuhan orang tua dan dapat menjelaskan penerimaan atau penolakan orang tua dalam interaksi orang tua dengan anaknya. PARQ terdiri dari 41 pernyataan dan empat poin skala Likert (yang kemudian diberi skor $0=$ tidak pernah hingga 3 = selalu). Cronbach's alpha persepsi remaja terkait pengasuhan orang tua sebesar 0,941. Behavioral control merupakan bagian dari $\mathrm{PARQ} /$ Control yang digunakan untuk mengukur persepsi remaja terhadap kontrol perilaku dari orang tua. Alat ukur ini terdiri dari 12 pernyataan dan empat poin skala Likert $(1=$ Tidak pernah hingga $4=$ Selalu) dengan Cronbach's alpha 0,741. Pada penelitian Kim (2008) menambahkan alat ukur Psychological Control Scale pada PARQ/Control. Menurut Barber (1996) kontrol psikologi dapat memicu gangguan psikologi dan perkembangan emosi pada anak. Alat ukur ini terdiri dari 8 pernyataan dan empat poin skala Likert (yang 
kemudian diberi skor $0=$ tidak pernah hingga 3 = selalu) dengan Cronbach's alpha 0,837.

Perkembangan sosial emosi remaja diukur dengan menggunakan instrumen Social Skill Inventory yang dikembangkan oleh Riggio (1986). Menurut Goleman (2006), kematangan emosi seseorang merupakan kunci keberhasilan dalam menjalin hubungan sosialnya. Kecakapan tersebut merupakan faktor utama dalam menunjang keberhasilan dalam pergaulan. Pada penelitian ini, menggunakan indikator keterampilan sosial untuk mengukur ketercapaian perkembangan sosial emosi remaja berdasarkan persepsi remaja. Menurut Riggio (1986), keterampilan sosial meliputi kemampuan dalam mengekspresikan, mengintepretasi, dan mengontrol pesan atau komunikasi verbal atau sosial dan non verbal atau emosi. Selanjutnya, Riggio membagi menjadi enam yakni emotional expressivity (EE), emotional sensitivity (ES), emotional control (EC), social expressivity (SE), social sensitivity (SS), dan social control (SC). Emotional expressivity/EE (ekspresi emosi) yakni keterampilan seseorang dalam berkomunikasi secara non verbal dengan mengekspresikan emosinya secara spontan dan akurat. Emotional sensitivity/ES (sensivitas emosi) yakni kemampuan individu dalam mengintepretasikan pesan emosi dari orang lain. Emotional control/EC (kontrol emosi) yakni kemampuan individu dalam mengendalikan dan mengatur perilaku emosional dan non verbal. Social expressivity/SE (ekspresi social) adalah keterampilan verbal dan kemampuan untuk mengajak orang lain berinteraksi. Social sensitivity/SS (sensivitas social) yakni kemampuan untuk mengintepretasikan dan memahami komunikasi verbal dan pengetahuan umum dari norma-norma yang mengatur tingkah laku sosial secara tepat. Social control/SC (kontrol sosial) yakni kemampuan individu dalam mengontrol sikap pada berbagai situasi (Sahalessy, 2017). Instrumen ini diadopsi dari penelitian Oldmeadow, Quinn dan Kowert (2013). Instrumen ini terdiri dari dua domain yakni emosi dan sosial. Domain emosi mencakup emotional expressivity, emotional sensitivity, dan emotional control. Domain sosial mencakup social expressivity, social sensitivity, dan social control. Instrumen ini terdiri dari 24 pernyataan dengan Cronbach's alpha 0,716. Instrumen dijawab dengan menggunakan empat skala Likert (yang kemudian diberi skor 0 $=$ tidak setuju hingga 3 = sangat setuju).

Data yang sudah terkumpul kemudian diolah dan dianalisis menggunakan Statistical
Package for Social Science (SPSS) dan Structural Equation Modelling (PLS-SEM). Masing-masing variabel penelitian diberi skor penilaian pada setiap pernyataan kuesioner. Setelah itu, skor total dari masing-masing variabel ditransformasikan menjadi indeks (0100). Hal ini bertujuan untuk menyamakan satuan agar perbandingan pengategorian data setiap variabel seragam. Pada pengolahan uji pengaruh dengan menggunakan PLS-SEM, beberapa indikator pernyataan pada masingmasing variabel yang tidak memenuhi uji validitas SPSS tidak dimasukkan dalam olahan uji pengaruh sehingga total indikator pernyataan yang diuji sebanyak 131 dari total 152 indikator pernyataan.

\section{HASIL}

\section{Karakteristik Remaja}

Hasil penelitian menunjukkan remaja laki-laki dan perempuan memiliki rataan usia masingmasing 15,37 tahun dan 15,61 tahun. Selain itu, sekitar tiga dari sepuluh remaja laki-laki $(21,7 \%)$ dan perempuan $(27,1 \%)$ berada pada kelompok usia 16 tahun.

\section{Karakteristik Keluarga}

Hasil penelitian menunjukkan rata-rata usia ayah adalah 47,63 tahun dan ibu 43,08 tahun. Rata-rata besar keluarga responden berkisar lima orang, berada pada kategori keluarga sedang (5-7 orang). Hasil penelitian menunjukkan rata-rata lama menikah pasangan ayah dan ibu pada remaja laki-laki berkisar 21,27 tahun dan rata-rata lama menikah pasangan ayah dan ibu berkisar 21,93 tahun pada responden perempuan. Rata-rata lama menetap keluarga remaja laki-laki dan perempuan berkisar 44,23 bulan. Capaian tingkat pendidikan ibu dan ayah pada responden laki-laki dan perempuan belum mencapai pendidikan wajib sembilan tahun. Responden perempuan memiliki rata-rata lama pendidikan ibu dan ayah masing-masing 8,92 tahun dan 10,46 tahun. Hasil lain juga menunjukkan bahwa rata-rata pendapatan perkapita keluarga responden laki-laki sebesar Rp710.000,00; lebih rendah dibandingkan dengan pendapatan perkapita keluarga responden perempuan sebesar Rp790.000,00. Hasil uji beda menunjukkan adanya perbedaan signifikan pada pendapatan perkapita keluarga responden laki-laki dan perempuan dengan $p$ value $=0,368(p \leq 0,05)$. 
Tabel 1 Sebaran keluarga menurut komponen tekanan ekonomi objektif keluarga berdasarkan jenis kelamin remaja serta nilai koefisien uji beda antara keluarga remaja laki-laki dan perempuan

\begin{tabular}{|c|c|c|c|}
\hline \multirow{2}{*}{$\begin{array}{l}\text { Karakteristik } \\
\text { tekanan ekonomi } \\
\text { objektif }\end{array}$} & \multicolumn{2}{|c|}{ Persentase } & \multirow[b]{2}{*}{$\begin{array}{c}p- \\
\text { value }\end{array}$} \\
\hline & $\begin{array}{l}\text { Keluarga } \\
\text { remaja } \\
\text { laki-laki }\end{array}$ & $\begin{array}{l}\text { Keluarga } \\
\text { remaja } \\
\text { perempuan }\end{array}$ & \\
\hline \multicolumn{4}{|l|}{ Tingkat kemiskinan } \\
\hline $\begin{array}{l}\text { Tidak miskin } \\
\text { (>Rp593.108,00) }\end{array}$ & 50 & 59,30 & \multirow{3}{*}{0,31} \\
\hline $\begin{array}{l}\text { Miskin } \\
(\leq \text { Rp593.108,00) }\end{array}$ & 50 & 40,70 & \\
\hline Total & 100 & 100 & \\
\hline \multicolumn{4}{|l|}{$\begin{array}{l}\text { Status pekerjaan } \\
\text { suami }\end{array}$} \\
\hline Tetap & 5 & 5,10 & \multirow{4}{*}{0,74} \\
\hline Tidak tetap & 71,70 & 74,60 & \\
\hline Tidak bekerja & 23,30 & 20,30 & \\
\hline Total & 100 & 100 & \\
\hline \multicolumn{4}{|l|}{$\begin{array}{l}\text { Perbandingan } \\
\text { pendapatan dan } \\
\text { pengeluaran }\end{array}$} \\
\hline $\begin{array}{l}\text { Pendapatan lebih } \\
\text { besar dari } \\
\text { pengeluaran }\end{array}$ & 51,70 & 47,50 & \multirow{4}{*}{0,72} \\
\hline $\begin{array}{l}\text { Pendapatan sama } \\
\text { dengan } \\
\text { pengeluaran }\end{array}$ & 0 & 1,70 & \\
\hline $\begin{array}{l}\text { Pendapatan lebih } \\
\text { kecil dari } \\
\text { pengeluaran }\end{array}$ & 48,30 & 50,80 & \\
\hline Total & 100 & 100 & \\
\hline \multicolumn{4}{|l|}{$\begin{array}{l}\text { Perbandingan } \\
\text { antara hutang dan } \\
\text { aset (rasio) }\end{array}$} \\
\hline Tidak berhutang & 35 & 30,50 & \multirow{4}{*}{0,73} \\
\hline$<50 \%$ & 36,70 & 40,70 & \\
\hline$>50 \%$ & 28,30 & 28,80 & \\
\hline Total & 100 & 100 & \\
\hline
\end{tabular}

\section{Tekanan Ekonomi Objektif}

Tekanan ekonomi objektif diukur dengan melihat tingkat kemiskinan, status pekerjaan suami, perbandingan pendapatan dan pengeluaran, serta rasio hutang dengan aset. Tabel 1 menunjukkan bahwa separuh (50\%) keluarga remaja laki-laki dan lebih dari sepertiga $(40,7 \%)$ keluarga responden perempuan pada kategori keluarga miskin. Berdasarkan garis kemiskinan BPS Provinsi DKI Jakarta (2018) sebesar Rp593.108,00, jika keluarga memiliki pendapatan per kapita kurang dari jumlah tersebut berada pada kategori keluarga miskin.Berdasarkan status pekerjaan ayah, kurang dari tiga perempat $(71,4 \%)$ keluarga remaja laki-laki dan perempuan $(74,6 \%)$ memiliki status pekerjaan tidak tetap.

Berdasarkan perbandingan pendapatan dan pengeluaran, sebesar 51,70 persen keluarga remaja laki-laki memiliki pendapatan lebih besar dari pengeluaran sedangkan keluarga remaja perempuan sebanyak 50,80 persen memiliki pendapatan lebih kecil dari pengeluaran. Sementara itu, berdasarkan perbandingan antara hutang dan aset ditemukan bahwa lebih dari satu perempat keluarga remaja laki-laki $(28,30 \%)$ dan perempuan $(28,80 \%)$ dinilai sangat rentan kondisi ekonominya. Hal ini disebabkan karena keluarga yang memiliki hutang lebih dari 50 persen aset yang dimiliki. Lebih lanjut, nilai hutang minimum keluarga responden yaitu sebesar Rp150.000,00 dan hutang tertinggi sebesar Rp22.517.550,00. Berdasarkan data yang diperoleh, hutang keluarga terbesar adalah tunggakan sewa rusunawa beserta dendanya.

Tabel 2 Rataan indeks dan uji beda komponen menurut tekanan ekonomi subjektif berdasarkan jenis kelamin

\begin{tabular}{|c|c|c|c|}
\hline \multirow{2}{*}{$\begin{array}{l}\text { Tekanan ekonomi } \\
\text { subjektif }\end{array}$} & \multicolumn{2}{|c|}{ Rataan } & \multirow{2}{*}{$\begin{array}{c}p- \\
\text { value }\end{array}$} \\
\hline & $\begin{array}{l}\text { Remaja } \\
\text { laki-laki }\end{array}$ & $\begin{array}{c}\text { Remaja } \\
\text { perempuan }\end{array}$ & \\
\hline $\begin{array}{l}\text { Orang tua } \\
\text { bertengkar karena } \\
\text { persoalan ketiadaan } \\
\text { uang }\end{array}$ & 20,90 & 28,09 & 0,59 \\
\hline $\begin{array}{l}\text { Orang tua kesal } \\
\text { karena mereka tidak } \\
\text { memiliki uang yang } \\
\text { cukup untuk } \\
\text { membayar } \\
\text { kebutuhan keluarga }\end{array}$ & 18,64 & 23,89 & 0,34 \\
\hline $\begin{array}{l}\text { Orang tua dan } \\
\text { remaja bertengkar } \\
\text { mengenai masalah } \\
\text { ekonomi }\end{array}$ & 10,17 & 13,89 & 0,42 \\
\hline $\begin{array}{l}\text { Memiliki kecukupan } \\
\text { uang untuk membeli } \\
\text { pakaian atau } \\
\text { kebutuhan aktivitas } \\
\text { sekolah atau lainnya } \\
\text { yang dibutuhkan*) }\end{array}$ & 59,44 & 58,76 & 0,35 \\
\hline $\begin{array}{l}\text { Memiliki kecukupan } \\
\text { uang untuk } \\
\text { melakukan aktivitas } \\
\text { bersama teman- } \\
\text { teman seperti } \\
\text { nonton film, makan } \\
\text { bersama dlı*) }\end{array}$ & 55,00 & 62,71 & 0,89 \\
\hline $\begin{array}{lr}\text { Orang tua tidak } \\
\text { memiliki uang yang } \\
\text { cukup } & \text { untuk } \\
\text { membeli } & \text { kebutuhan } \\
\text { keluarga } & \end{array}$ & 20,34 & 21,11 & 0,17 \\
\hline Total & 31,92 & 33,70 & 0,99 \\
\hline
\end{tabular}




\section{Tekanan Ekonomi Subjektif}

Tabel 2 menunjukkan, rataan indeks tekanan ekonomi subjektif yang dirasakan remaja perempuan $(33,70)$ dan remaja laki-laki $(31,92)$. Rataan skor indeks tertinggi yang dirasakan remaja laki-laki sebesar 59,46. Menurut remaja laki-laki, saat ini mereka merasa memiliki kecukupan uang untuk membeli pakaian atau kebutuhan sekolah lainnya. Remaja perempuan memiliki rataan skor tertinggi sebesar 62,71. Sementara itu, remaja perempuan merasa memiliki kecukupan uang untuk melakukan aktivitas bersama teman-teman seperti nonton di bioskop dan jalan-jalan. Selain itu, remaja laki-laki dan perempuan merasa hampir jarang bertengkar dengan orang tua terkait masalah uang. Hal ini ditunjukkan dengan rataan skor pada remaja perempuan sebesar 13,89 dan laki-laki sebesar 10,17. Hasil uji beda tidak menemukan adanya perbedaan signifikan pada tekanan ekonomi subjektif antara responden laki-laki dan perempuan.

\section{Interaksi Orang Tua-Remaja}

Tabel 3 menunjukkan total rataan indeks interaksi ayah-remaja pada remaja laki-laki sebesar 30,49 dan remaja perempuan sebesar 30,84 . Interaksi ibu-remaja memiliki total rataan indeks pada remaja laki-laki sebesar 32,65 dan remaja perempuan sebesar 31,87. Dimensi penerimaan memiliki rataan skor tertinggi pada interaksi ibu-remaja dan interaksi ayah-remaja, sedangkan rataan skor terendah pada dimensi pengabaian. Meskipun pengasuhan penerimaan ibu dan ayah memiliki rataan indeks tertinggi diantara dimensi lainnya namun remaja laki-laki dan perempuan masih merasakan adanya pengasuhan kekerasan baik dari ayah dan ibu seperti ibu memaki ketika marah, ayah memberikan hukuman ketika marah, dan ayah mengeluhkan kepada orang lain ketika tidak patuh.

Dimensi Penerimaan. Interaksi ayah-remaja menurut responden perempuan memiliki rataan indeks $(62,62)$ lebih tinggi dibandingkan responden laki-laki $(56,50)$ pada dimensi penerimaan ayah. Hasil uji beda menunjukkan adanya perbedaan signifikan dimensi penerimaan ayah ( $p$-value $=0,09)$. Hal ini bermakna bahwa menurut persepsi responden perempuan interaksi ayah-remaja pada dimensi penerimaan lebih hangat atau dekat dibandingkan dengan responden laki-laki yang menilai penerimaan ayah kurang hangat. Pada variabel interaksi ibu-remaja, hasil kajian menunjukkan responden perempuan memiliki rataan indeks tertinggi juga pada dimensi penerimaan ibu $(65,58)$ meskipun hasilnya tidak berbeda nyata dengan penerimaan ibu berdasarkan persepsi remaja laki-laki.

Dimensi Kekerasan. Hasil Tabel 3 menunjukkan rataan indeks interaksi ayahremaja yang ditinjau dari pengasuhan dimensi kekerasan pada remaja laki-laki sebesar 17,27 dan perempuan sebesar 12,19. Rataan indeks ibu-remaja pada remaja laki-laki sebesar 19,24 dan remaja perempuan sebesar 16,13 . Hasil uji beda menunjukkan tidak ada perbedaan signifikan pada dimensi kekerasan antara interaksi ayah-remaja dengan interaksi iburemaja.

Dimensi Pengabaian. Dimensi pengabaian memiliki rataan indeks terendah diantara lima dimensi lainnya. Rataan indeks tertinggi pada dimensi ini ditemukan pada remaja laki-laki baik dalam hal interaksi ayah-remaja maupun interaksi ibu-remaja. Menurut remaja laki-laki, pengasuhan pengabaian yang dirasakan remaja ketika ibu dan ayah kadang-kadang menilai bahwa anak lain bisa berperilaku baik dibandingkan dirinya.

Dimensi Behavioral Control. Tabel 3 menunjukkan rataan indeks interaksi ayahremaja pada remaja laki-laki sebesar 50,65 dan remaja perempuan sebesar 52,75 pada dimensi behavioral control.

Tabel 3 Rataan indeks dan uji beda menurut interaksi orang tua-remaja berdasarkan jenis kelamin

\begin{tabular}{|c|c|c|c|c|c|c|}
\hline \multirow[b]{2}{*}{ Dimensi } & \multicolumn{2}{|c|}{ Ayah } & \multirow[b]{2}{*}{$\begin{array}{l}p- \\
\text { Val } \\
\text { ue }\end{array}$} & \multicolumn{2}{|c|}{ Ibu } & \multirow[b]{2}{*}{$\begin{array}{l}p- \\
\text { Val } \\
\text { ue }\end{array}$} \\
\hline & $\begin{array}{c}\text { Re } \\
\text { maj } \\
\text { a } \\
\text { laki- } \\
\text { laki }\end{array}$ & $\begin{array}{c}\text { Remaj } \\
\text { a } \\
\text { perem } \\
\text { puan }\end{array}$ & & $\begin{array}{c}\text { Re } \\
\text { maj } \\
\text { a } \\
\text { laki- } \\
\text { laki }\end{array}$ & $\begin{array}{c}\text { Remaj } \\
\text { a } \\
\text { perem } \\
\text { puan }\end{array}$ & \\
\hline $\begin{array}{l}\text { Peneri } \\
\text { maan }\end{array}$ & $\begin{array}{r}56,5 \\
0\end{array}$ & 62,62 & $\begin{array}{r}0,0 \\
9^{*}\end{array}$ & $\begin{array}{r}62,3 \\
6\end{array}$ & 65,58 & $\begin{array}{r}0,3 \\
7\end{array}$ \\
\hline $\begin{array}{l}\text { Kekera } \\
\text { san }\end{array}$ & $\begin{array}{r}17,2 \\
7\end{array}$ & 12,79 & $\begin{array}{r}0,1 \\
1\end{array}$ & $\begin{array}{r}19,2 \\
4\end{array}$ & 16,13 & $\begin{array}{r}0,2 \\
6\end{array}$ \\
\hline $\begin{array}{l}\text { Pengab } \\
\text { aian }\end{array}$ & $\begin{array}{r}11,0 \\
2\end{array}$ & 7,63 & $\begin{array}{r}0,2 \\
3\end{array}$ & $\begin{array}{r}11,8 \\
5\end{array}$ & 9,13 & $\begin{array}{r}0,3 \\
4\end{array}$ \\
\hline $\begin{array}{l}\text { Behavio } \\
\text { ral } \\
\text { control }\end{array}$ & $\begin{array}{r}50,6 \\
5\end{array}$ & 52,75 & $\begin{array}{r}0,8 \\
6\end{array}$ & $\begin{array}{r}48,6 \\
1\end{array}$ & 48,45 & $\begin{array}{r}0,9 \\
9\end{array}$ \\
\hline $\begin{array}{l}\text { Psychol } \\
\text { ogical } \\
\text { control }\end{array}$ & $\begin{array}{r}17,0 \\
1\end{array}$ & 18,43 & $\begin{array}{r}0,6 \\
1\end{array}$ & $\begin{array}{r}21,1 \\
8\end{array}$ & 20,06 & $\begin{array}{r}0,6 \\
8\end{array}$ \\
\hline $\begin{array}{l}\text { Rataan } \\
\text { indeks } \\
\text { interaks } \\
\text { i orang } \\
\text { tua- } \\
\text { remaja }\end{array}$ & $\begin{array}{r}30,4 \\
9\end{array}$ & 30,84 & & $\begin{array}{r}32,6 \\
5\end{array}$ & 31,87 & \\
\hline
\end{tabular}


Menurut remaja laki-laki, ayah dan ibu jarang memberikan sebanyak mungkin kebebasan kepada remaja dan lebih membiarkan remaja laki-laki untuk pergi ke tempat-tempat yang disukai remaja tanpa bertanya terlebih dahulu kepada ibu dan ayah.

Dimensi Psychological Control. Hasil olahan menunjukkan dimensi psychological control interaksi ibu-remaja memiliki rataan indeks tertinggi ditemukan pada remaja laki-laki sebesar 21,18 sedangkan rataan indeks tertinggi interaksi ayah-remaja ditemukan pada remaja perempuan sebesar 18,34. Menurut remaja laki-laki, terkadang ibu membuka kesalahan lama ketika memberikan kritik. Sementara itu, menurut remaja perempuan, ayah kadang-kadang mengubah perasaan atau tentang sesuatu yang dipikirkan oleh remaja.

\section{Perkembangan Sosial Emosi Remaja}

Hasil Tabel 4 menunjukkan total rataan indeks perkembangan sosial emosi pada domain emosi remaja laki-laki sebesar 53,80 dan perempuan sebesar 51,46 . Sementara itu, pada domain sosial, rataan skor indeks remaja lakilaki sebesar 52,5 dan perempuan sebesar 50,85 . Hasil uji beda menunjukkan tidak ditemukan perbedaan signifikan diantara remaja laki-laki dan perempuan pada perkembangan sosial emosi remaja.

Emotional Expressivity. Tabel 4 menunjukkan rataan skor dimensi emotional expressivity pada remaja laki-laki adalah 58,19 dan remaja perempuan sebesar 56,64. Aspek dimensi emotional expressivity yang memiliki rataan indeks tertinggi yakni merasa nyaman ketika menyentuh fisik orang lain. Pada remaja perempuan, capaian rataan emotional expressivity merupakan rataan tertinggi dibandingkan dengan dimensi emosi lainnya.

Emotional Sensitivity. Dimensi ini memiliki rataan indeks terendah pada domain emosi yakni remaja laki-laki $(43,89)$ dan remaja perempuan $(42,37)$ (Tabel 4). Pada dimensi ini remaja laki-laki dan perempuan merasa mengalami kesulitan dalam memahami emosi dari orang lain. Hasil penelitian menunjukkan bahwa dimensi ini merupakan dimensi terendah baik pada remaja laki-laki maupun perempuan pada domain perkembangan emosi.

Emotional Control. Selanjutnya, hasil Tabel 4 menunjukkan rataan indeks emotional control remaja laki-laki sebesar 59,31 dan remaja perempuan sebesar 55,37 . Pada remaja lakilaki, capaian rataan emotional control merupakan rataan tertinggi dibandingkan dengan dimensi emosi lainnya.

Social Expressivity. Tabel 4 menunjukkan rataan indeks social expressivity remaja perempuan sebesar 57,34 dan remaja laki-laki sebesar 55,28. Pada dimensi ini sebagian besar remaja laki-laki dan perempuan menikmati bersosialisasi dengan lingkunganya. Hasil penelitian juga menunjukkan bahwa dimensi ini memiliki capaian tertinggi baik pada remaja perempuan maupun remaja laki-laki pada domain perkembangan emosi.

Social Sensitivity. Hasil penelitian menunjukkan bahwa rataan indeks dimensi social sensitivity pada remaja laki-laki sebesar 50,00 dan perempuan yaitu sebesar 50,85 (Tabel 4). Pada dimensi ini, remaja laki-laki dan perempuan menilai sangat memperhatikan kesan yang akan diberikan kepada orang lain.

Social Control. Dimensi social control memiliki rataan indeks terendah baik pada remaja lakilaki yaitu sebesar 50,00 maupun pada remaja perempuan yaitu sebesar 46,19. Hasil ini menyimpulkan bahwa remaja laki-laki dan perempuan menikmati bersosialisasi, dapat berbicara banyak dengan orang-orang yang berbeda. Akan tetapi, pada dimensi social control menunjukkan remaja laki-laki dan perempuan jarang menjadi juru bicara di dalam kelompok, menemukan kesulitan yang besar berbicara dihadapan orang banyak, dan jarang ditunjuk sebagai pemimpin kelompok.

Tabel 4 Rataan indeks dan uji beda menurut perkembangan sosial emosi remaja berdasarkan jenis kelamin

\begin{tabular}{lccc}
\hline $\begin{array}{c}\text { Domain } \\
\text { perkembangan dan } \\
\text { dimensi }\end{array}$ & $\begin{array}{c}\text { Remaja } \\
\text { laki-laki }\end{array}$ & $\begin{array}{c}\text { Remaja } \\
\text { perempuan }\end{array}$ & $\begin{array}{c}p- \\
\text { value }\end{array}$ \\
\hline $\begin{array}{l}\text { Emosi } \\
\text { Emotional } \\
\text { expressivity }\end{array}$ & 58,19 & 56,64 & 0,65 \\
$\begin{array}{l}\text { Emotional } \\
\text { sensitivity }\end{array}$ & 43,89 & 42,37 & 0,73 \\
$\begin{array}{l}\text { Emotional control } \\
\text { Rataan indeks }\end{array}$ & 59,31 & 55,37 & 0,29 \\
domain & & & \\
perkembangan & 53,80 & 51,46 & 0,29 \\
emosi & & & \\
\hline $\begin{array}{l}\text { Sosial } \\
\text { Social expressivity }\end{array}$ & 55,28 & 57,34 & 0,61 \\
$\begin{array}{l}\text { Social sensitivity } \\
\text { Social control }\end{array}$ & 52,22 & 49,01 & 0,41 \\
$\begin{array}{l}\text { Rataan indeks } \\
\text { domain } \\
\text { perkembangan }\end{array}$ & 50,00 & 46,19 & 0,31 \\
sosial & 52,50 & 50,85 & 0,55 \\
\hline
\end{tabular}


Pengaruh Karakteristik Remaja, Karakteristik Keluarga, dan Interaksi Orang Tua-Remaja Terhadap Perkembangan Sosial Emosi Remaja

Hasil uji pengaruh model karakteristik remaja, karakteristik keluarga, tekanan ekonomi, dan interaksi orang tua-remaja terhadap perkembangan sosial emosi remaja menunjukkan angka $R$-square sebesar 0,169 (Gambar 1) yang berarti model menjelaskan 16,9 persen variabel yang memengaruhi perkembangan sosial emosi remaja dan sisanya 83,1 persen dipengaruhi oleh variabel lainnya yang tidak diteliti dalam penelitian ini. Temuan uji pengaruh Gambar 1 menunjukkan capaian perkembangan sosial emosi remaja dipengaruhi langsung positif oleh karakateristik remaja $(\beta=0,236 ; t>1,96)$ dan interaksi iburemaja $(\beta=0,306 ; t>1,96)$, dan dipengaruhi tidak langsung negatif oleh tekanan ekonomi objektif. Karakteristik remaja yang dimaksud yakni usia remaja; dan interaksi ibu-remaja yang dimaksud yakni penerimaan ibu, behavioral control ibu, dan psychological control ibu. Temuan uji pengaruh menunjukkan peningkatan usia remaja dan peningkatan kualitas interaksi ibu-remaja pada dimensi penerimaan ibu, behavioral control ibu, dan psychological control ibu maka akan menyebabkan peningkatan capaian perkembangan sosial emosi remaja pada dimensi social sensitivity dan social expressivity.

Temuan lain yang ditemukan pada uji pengaruh yakni adanya pengaruh negatif tidak langsung dari tekanan ekonomi objektif $(\beta=-0,078$, $t>1,96)$ terhadap perkembangan sosial emosi remaja melalui interaksi ibu-remaja. Hal ini berarti peningkatan tekanan ekonomi objektif maka menyebabkan penurunan interaksi iburemaja sehingga penurunan interaksi iburemaja ini akan menyebabkan penurunan capaian perkembangan sosial emosi remaja.

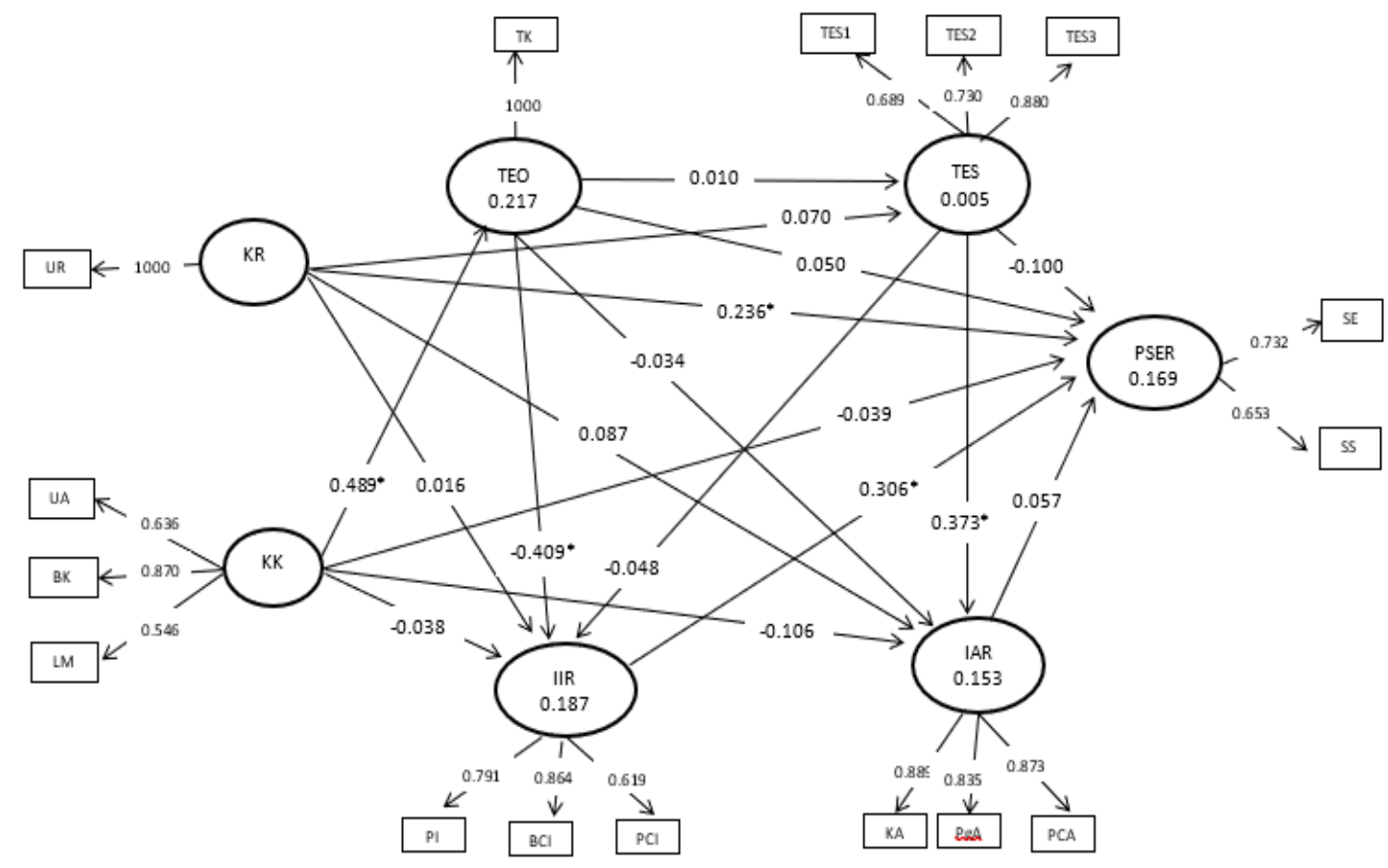

Keterangan:

$\mathrm{KR}=$ Karakteristik remaja,

UR = Usia remaja,

$\mathrm{KK}=$ Karakteristik keluarga,

$\mathrm{UA}=$ Usia ayah,

$\mathrm{BK}=$ Besar keluarga,

$\mathrm{LM}=$ Lama menikah,

TEO= Tekanan ekonomi objektif keluarga,

TK = Tingkat kemiskinan,

TES $=$ Tekanan ekonomi subjektif,

IIR = Interaksi ibu-remaja,
$\mathrm{PI}=$ Penerimaan ibu,

$\mathrm{BCl}=$ Behavioral control ibu,

$\mathrm{PCl}=$ Psychological control ibu,

IAR = Interaksi ayah-remaja,

$\mathrm{KA}=$ Kekerasan ayah,

$\mathrm{PgA}=$ Pengabaian ayah

PCA = Psychological control ayah,

PSER= Perkembangan sosial emosi remaja,

SS = Social Sensitivity,

$\mathrm{SE}=$ Social expressivity.

Gambar 1 Model PLS SEM 
Tabel 5 Koefisien pengaruh karakteristik remaja, karakteristik keluarga, tekanan ekonomi, dan interaksi orang tua remaja terhadap perkembangan sosial emosi remaja

\begin{tabular}{|c|c|c|c|c|c|c|}
\hline \multirow{3}{*}{ Variabel } & \multirow{3}{*}{$\mathrm{DE}$} & \multicolumn{4}{|c|}{$\begin{array}{c}\text { Perkembangan sosial } \\
\text { emosi remaja }\end{array}$} & \multirow{3}{*}{ TE } \\
\hline & & \multicolumn{4}{|c|}{ IE melalui } & \\
\hline & & $\begin{array}{c}\mathrm{TE} \\
\mathrm{O}\end{array}$ & $\begin{array}{c}\mathrm{TE} \\
\mathrm{S}\end{array}$ & IIR & $\begin{array}{l}\mathrm{IA} \\
\mathrm{R}\end{array}$ & \\
\hline $\begin{array}{l}\text { Karakteris } \\
\text { tik remaja }\end{array}$ & $\begin{array}{c}0,23 \\
6^{*}\end{array}$ & - & - & - & - & $\begin{array}{c}0,23 \\
6^{*}\end{array}$ \\
\hline $\begin{array}{l}\text { Karakteris } \\
\text { tik } \\
\text { keluarga }\end{array}$ & $\begin{array}{c}- \\
0,03 \\
9\end{array}$ & - & - & - & - & $\begin{array}{c}- \\
0,03 \\
9\end{array}$ \\
\hline $\begin{array}{l}\text { Tekanan } \\
\text { ekonomi } \\
\text { objektif }\end{array}$ & $\begin{array}{c}0,05 \\
0\end{array}$ & - & - & $\begin{array}{c}- \\
0,12 \\
8\end{array}$ & - & $\begin{array}{c}- \\
0,07 \\
8^{*}\end{array}$ \\
\hline $\begin{array}{l}\text { Tekanan } \\
\text { ekonomi } \\
\text { subjektif } \\
\text { remaja }\end{array}$ & $\begin{array}{c}- \\
0,09\end{array}$ & - & - & - & - & $\begin{array}{c}- \\
0,09\end{array}$ \\
\hline $\begin{array}{l}\text { Interaksi } \\
\text { ibu- } \\
\text { remaja }\end{array}$ & $\begin{array}{c}0,30 \\
6^{*}\end{array}$ & - & - & - & - & $\begin{array}{c}0,30 \\
6^{*}\end{array}$ \\
\hline $\begin{array}{l}\text { Interaksi } \\
\text { ayah- } \\
\text { remaja }\end{array}$ & $\begin{array}{c}0,05 \\
7\end{array}$ & - & - & - & - & $\begin{array}{c}0,05 \\
7\end{array}$ \\
\hline
\end{tabular}

\section{PEMBAHASAN}

Periode remaja merupakan periode penting dalam perkembangan manusia. Pada periode ini, remaja tidak hanya mengalami pertumbuhan dan perubahan fisik, tetapi juga perubahan dan pertumbuhan emosi, psikologis, sosial, mental (Brown \& Prinstein, 2011), dan pencarian identitas, serta membentuk hubungan baru dalam rangka mengekpresikan perasaan seksual (Santrock, 2003). Remaja dituntut dapat bersosialisasi dengan lingkungan sekitar dan menjalin interaksi sosial yang lebih kompleks sehingga diharapkan remaja memiliki hubungan sosial yang matang dan mendapat penerimaan dalam hubungan sosial tersebut didalam hidup bermasyarakat (Mappiare, 1982). Orang tua adalah aktor utama yang memengaruhi anak dan sumber daya bagi kehidupan anak. Kondisi ekonomi yang sulit, ketidakmampuan memberikan nafkah, pengangguran merupakan suatu kondisi yang membuat orang tua secara emosi, merasa takut dan cemas karena tidak dapat memenuhi kebutuhan keluarga dan akan memengaruhi pengasuhan yang diberikan kepada anak (Hastuti, 2008). Kesulitan ekonomi yang dihadapi orang tua berkaitan dengan berbagai resiko terhadap perkembangan sosial emosi anak (Barnett, 2008). Social sensitivity dan social expressivity dibutuhkan remaja untuk komunikasi sosialnya karena dapat memudahkan remaja dalam memulai dan mempertahankan sebuah interaksi sosial yang positif (Marheni, Made, \& Susilawati, 2019). Hasil uji pengaruh penelitian ini menemukan, perkembangan sosial emosi remaja pada dimensi social sensitivity dan social expressivity dipengaruhi langsung positif oleh usia remaja dan interaksi ibu-remaja pada dimensi penerimaan ibu, behavioral control ibu, dan psychological control ibu.

Menurut Hurlock (1989) dalam Sahalessy (2017), faktor usia memberi kesan bahwa kematangan sosial terjadi pada usia yang lebih tua, hal ini berarti peningkatan usia remaja maka menyebabkan peningkatan pula kemampuan sosialnya. Menurut Maharani, Masya, dan Janah (2018), pencapaian keterampilan sosial yang baik ditandai dengan kematangan sosial seseorang. Untuk mencapai pada tahapan ini, seseorang perlu belajar melalui berbagai pengalaman bergaul dengan orang-orang yang ada disekitar lingkungannya.

Penelitian yang menggunakan teori PAR (parental acceptance rejection) oleh Rohner, Khaleque dan Cournoyer (2007) dalam Kim (2008) menunjukkan, pola asuh orang tua, baik yang menerima (acceptance) maupun yang menolak (rejection) anaknya akan memengaruhi perkembangan emosi, perilaku, sosial kognitif, serta fungsi psikologinya. Pada penelitian ini menemukan, interaksi ibu-remaja berpengaruh langsung positif pada perkembangan sosial emosi remaja. Menurut Monks (1992), di dalam keluarga ibu bersikap lebih menerima, lebih mengerti, lebih koperatif terhadap anak dibandingkan dengan ayah. Hal ini ditunjukkan melalui pengasuhan bahwa ibu pemberi rasa aman, kasih sayang, dan tempat curahan hati, dengan kata lain ibu lebih menaruh perhatian dan lebih aktif dalam perkembangan remaja (Nora \& Widuri, 2011). Hasil penelitian Nurtami dan Supraptiningsih (2015) menunjukkan, remaja yang mempersepsikan pengasuhan orang tua yang selalu terlibat saat keluarga berkumpul dan mau mendengarkan serta memberi respon yang baik ketika remaja bercerita memiliki hubungan negatif pada pencapaian keterampilan sosial remaja yang buruk. Pada penelitian ini, selain remaja merasakan pengasuhan penerimaan ibu, remaja juga merasakan adanya behavioral control dan psychological control ibu. Hal tersebut mengindikasikan, tekanan ekonomi objektif pada tingkat kemiskinan keluarga berpengaruh 
tidak langsung negatif pada perkembangan sosial emosi remaja melalui interaksi iburemaja. Menurut Conger et al. (1992), indikator pendapatan perkapita dan ketidakstabilan pekerjaan dapat menentukan kondisi objektif ekonomi keluarga.

Tekanan ekonomi yang dirasakan keluarga menyebabkan terjadinya tekanan psikologis (psychological distres) pada orang tua yang dapat menimbulkan permasalahan perkawinan (Masarik dan Conger, 2017) dan memberikan dampak negatif pada perkembangan anak (Barnett, 2008). Menurut Leinonen et al. (2002), orang tua dengan stres yang lebih tinggi, menunjukkan pengasuhan kurang responsif, kurang hangat, kurang aktif, dan kurang menampilkan keterlibatannya. Selain itu, orang tua lebih banyak menunjukkan kemarahan, mengontrol perilaku anak, dan penuh dengan kritikan. Tingkat stres orang tua juga terkait dengan kualitas interaksi orang tua dan anak yang akan memberikan dampak pada perkembangan dan kesehatan mental anak (Weiss, 2009). Tekanan ekonomi subjektif merupakan penilaian yang diberikan remaja terkait permasalahan ekonomi yang dialami keluarga dan kecukupan uang yang dimiliki remaja untuk membeli kebutuhan yang diperlukan. Persepsi remaja tentang kesulitan ekonomi keluarga dapat memrediksi penyesuaian yang dilakukan oleh remaja sehingga memberikan pengaruh pada hubungan orang tua-remaja (McLoyd, 1990; Stein et al., 2013). Hasil uji pengaruh menunjukkan, tekanan ekonomi subjektif berpengaruh langsung positif terhadap interaksi ayah-remaja pada dimensi kekerasan, pengabaian, dan psychological control.

Elder et al. (1985) mengungkapkan, kesulitan ekonomi secara tidak langsung akan memengaruhi suasana hati orang tua, proses interaksi dalam keluarga, dan penyesuaian remaja melalui pengaruh tekanan ekonomi yang dirasakan orang tua. Temuan pada penelitian ini dapat dijelaskan mengingat salah satu peran penting ayah di keluarga adalah economic provider. Adanya tuntutan kebutuhan yang besar terkadang ayah akan melakukan pekerjaan sampingan untuk mencari penghasilan tambahan agar kebutuhan keluarga terpenuhi (Partasari, Lentari, \& Priadi 2017; Priatini, Latifah, \& Guhardja, 2008). Keluarga dengan pendapatan kecil memiliki kecenderungan kurang dalam memberikan perhatian terhadap kebutuhan dan perilaku anak (Voluntir \& Alfiasari, 2014). Hasil uji beda menunjukkan adanya perbedaan signifikan pada dimensi penerimaan ayah ( $p$-value $=0,09$ )
Artinya, menurut persepsi remaja perempuan bahwa interaksi ayah-remaja pada dimensi penerimaan lebih hangat atau dekat dibandingkan dengan remaja laki-laki yang menilai penerimaan ayah kurang hangat. Hal ini sejalan dengan penelitian Fatmasari (2013) pada keluarga jawa bahwa anak perempuan merasa lebih dekat dengan ayah dibanding anak laki-laki. Alasan kuat adanya kedekatan antara anak perempuan dengan ayahnya ialah karena ayah mampu untuk memahami, menyayangi, dan membimbing dalam berperilaku baik. Setiap penelitian memiliki keterbatasan dalam pelaksanaannya yang nantinya dapat dikaji lebih lanjut pada penelitian selanjutnya. Pengukuran pencapaian perkembangan sosial emosi remaja dilakukan hanya berfokus pada karakteristik remaja, karakteristik keluarga, tekanan ekonomi, dan interaksi orang tua-remaja. Untuk penelitian selanjutnya, pengambilan data terkait persepsi ibu dan persepsi ayah tentang interaksi orang tua-remaja perlu dilakukan. Hal ini berkenaan dengan fungsi struktural di dalam keluarga terutama antara orang tua-anak dapat diasumsikan melalui aturan dan fungsi yang dijalankan oleh setiap anggota keluarga yang akan membentuk generasi yang lebih baik.

\section{SIMPULAN DAN SARAN}

Rata-rata usia remaja perempuan 15,61 tahun dan 15,37 rata-rata usia remaja laki-laki. Ratarata usia ayah 47,63 tahun dan ibu 43,08 tahun. Rata-rata besar keluarga berada pada kategori sedang (5-7 orang), rata-rata lama menikah 21,6 tahun, dan rata-rata keluarga tinggal di rusunawa selama 44,23 bulan. Hasil uji beda menunjukkan adanya perbedaan pada pendapatan perkapita dan dimensi penerimaan ayah pada remaja laki-laki dan perempuan. Hasil uji pengaruh menunjukkan, usia remaja dan interaksi ibu-remaja berpengaruh langsung positif pada perkembangan sosial emosi remaja. Hasil uji hubungan menunjukkan behavioral control berhubungan positif dengan lama pendidikan ibu, lama pendidikan ayah, dimensi penerimaan dan domain sosial pada perkembangan sosial emosi remaja. Dimensi psychological control berhubungan positif dengan lama pendidikan ayah, dimensi kekerasan, dan dimensi pengabaian. Besar keluarga memiliki hubungan negatif dengan dimensi penerimaan. Pendapatan perkapita berhubungan negatif dengan tekanan ekonomi objektif. Tekanan ekonomi subjektif remaja memiliki hubungan negatif dengan dimensi penerimaan tetapi berhubungan positif dengan dimensi kekerasan. Hasil uji pengaruh menunjukkan bahwa perkembangan sosial 
emosi remaja dipengaruhi secara langsung positif oleh usia remaja dan interaksi ibu-remaja namun dipengaruhi secara tidak langsung negatif oleh tekanan ekonomi objektif melalui interaksi ibu-remaja.

Berdasarkan temuan penelitian maka saran yang dapat diberikan yakni pertama, pentingnya keterlibatan orang tua dalam membangun interaksi yang penuh kehangatan dan kasih sayang agar perkembangan sosial emosi remaja dapat tercapai dengan baik. Kedua, remaja perlu mengembangkan keterampilan sosial melalui kegiatan-kegiatan pelatihan atau aktif mengikuti kegiatan ekstrakurikuler yang disediakan oleh sekolah atau kegiatan yang disediakan oleh lingkungan. Ketiga, sekolah perlu mengembangkan model pembelajaran kooperatif agar keterampilan sosial remaja berkembang baik. Keempat, instansi pemerintah atau LSM menyediakan pelatihan bagi orang tua agar meningkatkan pengetahuan tentang pengasuhan remaja terutama bentuk-bentuk stimulus yang tepat untuk mendukung tercapainya perkembangan sosial emosi remaja serta seminar bagi orang tua agar mengembangkan pengasuhan dengan penuh kehangatan dan kasih sayang serta membangun komunikasi positif kepada remaja serta pelatihan keterampilan sosial bagi remaja. Terakhir, penelitian ini memberikan informasi adanya pengaruh interaksi ibu-remaja terhadap perkembangan sosial emosi remaja berdasarkan perspektif remaja sehingga dalam penelitian selanjutnya diharapkan dapat melakukan pengambilan data berdasarkan perspektif ibu. Hal lain yang menarik yakni perlu adanya pendalaman persepsi remaja terhadap permasalahan ekonomi keluarga.

\section{DAFTAR PUSTAKA}

[BKKBN] Badan Kependudukan dan Keluarga Berencana Nasional. (2017). Membangun Indonesia Mulai dari Keluarga. Jakarta, ID: BKKBN.

Andayani, T. R. (2010). Penyesuaian sosial siswa akselerasi ditinjau dari konsep diri dan membuka diri. Jurnal Pendidikan dan Kebudayaan, 16(7), 13-20. doi:http://dx .doi.org/10.24832\%2Fjpnk.v16i7.503.

Armayati, L., Iskandar, Z., Siswandi, A. G. P., \& Abidin, Z. (2019). Proses dinamika pembentukan identitas sosial pada kelompok: Studi kasus geng motor ghost night di Pekanbaru. Jurnal Psikologi, 15(1), 35-42. /jp.v15i1.6847.
Asilah, A., \& Hastuti, D. (2014). Hubungan tingkat stres ibu dan pengasuhan penerimaan penolakan dengan konsep diri remaja pada keluarga bercerai. Jur. IIm. Kel \& Kons, 7(1), 10-18. doi:https://doi.org/10 .24156/jikk.2014.7.1.10.

Barber, B. K. (1996). Parental psychological control: Revisiting a neglected construct. Child development, 67(6), 32963319 . doi:10.1111/j.14678624.1996.tb01915.x.

Barnett, M. A. (2008). Economic disadvantage in complex family systems: Expansion of family stress models. Clinical Child and Family Psychology Review, 11(3), 145161. doi:https://doi.org/10.1007/s10567008-0034-z

Berns, R. (1993). Child, family, community: Socialization and support. San Francisco, CA: Wadsworth Cengage Learning.

Brown, B. B., \& Prinstein, M. J. (2011). Encyclopedia of adolescence. Boston, US: Academic Press.

Conger, R. D., Conger, K. J., Elder Jr, G. H., Lorenz, F. O., Simons, R. L., \& Whitbeck, L. B. (1992). A family process model of economic hardship and adjustment of early adolescent boys. Child Development, 63(3), 526-541. doi:10.1111 /j.1467-8624.1992.tb01644.x

Conger, R. D., Conger, K. J., Matthews, L. S., \& Elder Jr, G. H. (1999). Pathways of economic influence on adolescent adjustment. American Journal of Community Psychology, 27(4), 519-541. doi:10.1023/A:1022133228206

Conger, R. D., Elder Jr, G. H., Lorenz, F. O., Conger, K. J., Simons, R. L., Whitbeck, L. B., \& Melby, J. N. (1990). Linking economic hardship to marital quality and instability. Journal of Marriage and the Family, 52(3), 643-656. doi:10.2307/ 352931 .

Downey, G., \& Coyne, J. C. (1990). Children of depressed parents: an integrative review. Psychological bulletin, 108(1), 5076. doi:10.1037/0033-2909.108.1.50

Elder, Jr. G. H., Van-Nguyen, T., \& Caspi, A. (1985). Linking family hardship to children's lives. Child Development, 56(2), 361-375. doi:10.2307/1129726.

Fatmasari A. E. (2013). Dinamika kedekatan hubungan orang tua-anak: Perbedaan kedekatan ayah-ibu dengan anak laki-laki dan anak perempuan tahap remaja akhir pada keluarga Jawa (Doctoral Dissertation 
Abstraction). Yogyakarta, ID: Universitas Gadjah Mada.

Firdaus, F., \& Sunarti, E. (2009). Hubungan antara tekanan ekonomi dan mekanisme koping dengan kesejahteraan keluarga wanita pemetik teh. Jurnal Ilmu Keluarga \& Konsumen, 2(1), 21-31. doi:https://doi.org /10.24156/jikk.2009.2.1.21.

Galambos, N. L., \& Silbereisen, R. K. (1987). Influences of income change and parental acceptance on adolescent transgression proneness and peer relations. European Journal of Psychology of Education, 1(4), 17.

doi:https://doi.org/10.1007/BF03172636.

Goleman, D. (2006). Emotional intelligence (kecerdasan emosional): Mengapa IE lebih penting daripada IQ. Penerjemah: T. Hermaya. Jakarta, ID: Gramedia Pustaka Utama.

Gudmunson C. G. (2010). A life course investigation of financial self-reliance and economic pressure in early adulthood (Dissertation). Minnesota, US: Minnesota University.

Hastuti, D. (2008). Pengasuhan: Teori, prinsip dan aplikasinya. Bogor, ID: IPB Press.

Khaleque, A., \& Rohner, R. P. (2002). Perceived parental acceptance-rejection and psychological adjustment: A meta-analysis of cross-cultural and intracultural studies. Journal of Marriage and Family, 64(1), 54-64. https://doi.org/10.1111/j.17413737.2002.00054.x

Kim, A. H. (2008). Korean parents' and adolescents' reports of parenting styles: $A$ developmental study (Dissertation). College Park, US: University of Maryland.

Larasati, K., \& Marheni, A. (2019). Hubungan antara komunikasi interpersonal orang tuaremaja dengan keterampilan sosial remaja. Jurnal Psikologi Udayana, 6(2), 1093-1100. doi:https://doi.org/10.24843/jpu .v6i02.48662.

Leinonen, J. A., Solantaus, T. S., \& Punamäki, R. L. (2002). The specific mediating paths between economic hardship and the quality of parenting. International Journal of Behavioral Development, 26(5), 423435. doi:10.1080/01650250143000364.

Maharani, L., Masya, H., \& Janah, M. (2018). Peningkatan keterampilan sosial peserta didik SMA menggunakan layanan bimbingan kelompok dengan teknik diskusi. KONSELI: Jurnal Bimbingan dan Konseling (E-Journal), 5(1), 65-72. doi:https://doi.org/10.24042/kons.v5i1.265 8

Malti, T., \& Noam, G. G. (2016). Socialemotional development: From theory to practice. European Journal of Developmental Psychology, 13(6), 652665. doi:10.1080/17405629.2016.1196178

Mappiare, A. (1982). Psikologi remaja. Surabaya, ID: Usaha Nasional.

Marheni, A., Made, I. R., \& Susilawati, L. K. P. A. (2019). Peran kualitas kelekatan anak dengan orang tua pada keterampilan sosial remaja. Jurnal IImu Perilaku, 2(2), 118-130. doi:https://doi.org/10.2507 7/jip.2.2.118-130.2018.

Masarik, A. S., \& Conger, R. D. (2017). Stress and child development: $A$ review of the Family Stress Model. Current Opinion in Psychology, 13, 85-90. https://doi.org/ 10.1016/j.copsyc.2016.05.008

McLoyd, V. C. (1990). The impact of economic hardship on black families and children: psychological distress, parenting, and socioemotional development. Child Development, 61(2), 311-346. doi:https://doi.org/10.1111/j.14678624.1990.tb02781.x

Nora, A. C., \& Widuri, E. L. (2011). Komunikasi ibu dan anak dengan depresi pada remaja. Humanitas: Jurnal Psikologi Indonesia, 8(1), 45-61. doi:10.26555/humanitas.v8i1.457.

Nurtami, E. P. \& Supraptiningsih, E. (2015). Hubungan antara persepsi terhadap pola asuh orang tua dengan keterampilan sosial buruk pada remaja kelas XI di SMAN 1 Bandung. Prosiding Psikologi, 1(2), 271-278.

Oldmeadow, J. A., Quinn, S., \& Kowert, R. (2013). Attachment style, social skills, and facebook use amongst adults. Computers in Human Behavior, 29(3), 1142-1149. doi:https://doi.org/10.1016/j.chb.2012.10.0 06.

Partasari, W. D., Lentari, F. R. M., \& Priadi, M. A. G. (2017). Gambaran keterlibatan ayah dalam pengasuhan anak usia remaja (Usia 16-21 Tahun). Jurnal Psikogenesis, 5(2), 159-167. doi:https://doi.org/10. 24854/jps.v5i2.54.

Permatasari, M. F., \& Sastrawan, A. (2018). The influence of the numbers of residents to the function and convenience of motion on rusunawa, west Jatinegara, Jakarta's residential units. Riset Arsitektur (RISA), 2(3), 299-316. doi:https://doi.org /10.26593/risa.v2i03.2948.299-316. 
Priatini, W., Latifah, M., \& Guhardja, S. (2008). Pengaruh tipe pengasuhan, lingkungan sekolah, dan peran teman sebaya terhadap kecerdasan emosional remaja. Jurnal IImu Keluarga \& Konsumen, 1(1), 43-53. doi:https://doi. org/10.24156/jikk/2008.1.1.43

Purwaningsih, E., Tukiran, T., \& Giyarsih, S. R. (2011). Penyesuaian diri penghuni rumah susun terhadap lingkungan tempat tinggal. Majalah Geografi Indonesia, 25(2), 150-161, doi:https://doi.org/10.22146 /mgi.13397

Riggio, R. E. (1986). Assessment of basic social skills. Journal of Personality and social Psychology, 51(3), 649-660. doi:10.1037/0022-3514.51.3.649

Riska, H. A., \& Krisnatuti, D. (2017). Selfesteem remaja perempuan dan kaitannya dengan pengasuhan penerimaanpenolakan ibu dan interaksi saudara kandung. Jurnal IImu Keluarga \& Konsumen, 10(1), 24-35. doi:https://doi.org /10.24156/jikk.2017.10.1.24

Sahalessy, Y. C. (2017). Hubungan pola asuh orang tua dengan keterampilan sosial remaja di Kota Depok (Tesis). Depok, ID: Fakultas IImu Keperawatan Peminatan Keperawatan Komunitas Universitas Indonesia.

Santrock, J. W. (2003). Adolescence: Perkembangan remaja edisi keenam. Jakarta, ID: Erlangga.

Sari, D. K., \& Karyono, K. (2017). Kesesakan dan agresivitas pada remaja di kawasan Tambak Lorok Semarang. Empati, 5(1), 10-13.

Setiawan, H. H. (2016). Penanganan permasalahan tawuran remaja melalui pusat pengembangan remaja (Ppr) Di Cipinang Besar Utara, Jakarta Timur. Sosio Konsepsia, 5(2), 1-17. doi:https://doi.org/10.33007/ska.v5i2.131

Simons, R. L., Whitbeck, L. B., \& Wu, C. (1994). Resilient and vulnerable adolescents: Families in troubled times: Adapting to change in rural America. New York, US: Walter de Gruyter, Inc.

Stein, C. H., Hoffmann, E., Bonar, E. E., Leith, J. E., Abraham, K. M., Hamill, A. C., \& Fogo, W. R. (2013). The United States economic crisis: Young adults' reports of economic pressures, financial and religious coping and psychological wellbeing. Journal of Family and Economic Issues, 34(2), 200-210. doi:https://doi.org /10.1007/s10834-012-9328-x

Steinberg, L. (2001). We know some things: Parent-adolescent relationships in retrospect and prospect. Journal of Research On Adolescence, 11(1), 1-19. doi:https://doi.org/10.1111/15327795.00001

Sumara, D. S., Humaedi, S., \& Santoso, M. B. (2017). Kenakalan remaja dan penanganannya. Prosiding Penelitian dan Pengabdian Kepada Masyarakat, 4(2), 346-353. doi:https://doi.org/10.24198 /jppm.v4i2.14393.

Sunarti, E. (2012). Keragaan ketahanan keluarga indonesia: Pembangkitan teori (middle range theory) dan rumusan kebijakan ketahanan keluarga Indonesia. Bogor, ID: Institut Pertanian Bogor.

Sunarti, E., Atat, R., Noorhaisma, \& Lembayung, D. P. (2005). Pengaruh tekanan ekonomi keluarga, dukungan sosial, kualitas perkawinan, pengasuhan, dan kecerdasan emosi anak terhadap prestasi belajar anak. Media Gizi \& Keluarga, 29(1), 34-40. doi:http://repository .ipb.ac.id/handle/123456789/52156.

Syafruddin, P., \& Adi, I. R. (2017). Relokasi berdampak terhadap kesejahteraan dari sisi kondisi ekonomi warga Kampung Pulo. Jurnal IImu Kesejahteraan Sosial, 18(2), 124-138. doi:http://dx.doi. org/10.7454/jurnalkessos.v18i2.103

Unayah, N., \& Sabarisman, M. (2016). Fenomena kenakalan remaja dan kriminalitas. Sosio informa, 1(2), 121-140. doi:https://doi.org/10.33007/inf.v1i2.142

Voluntir, F., \& Alfiasari. (2014). Penerimaan orang tua menentukan lingkungan pengasuhan keluarga dengan anak remaja di wilayah suburban. Jurnal Pendidikan Karakter, 3(2014), 294-306, doi:10.21831/jpk.v0i3.5634

Weiss, K. (2009). Parental stress and relational quality in the parent-child dyad. New York, US: ETD Collection for Pace University. 